\title{
Spathebothriidea: survey of species, scolex and egg morphology, and interrelationships of a non-segmented, relictual tapeworm group (Platyhelminthes: Cestoda)*
}

\author{
Roman Kuchta ${ }^{1}$, Rebecca Pearson ${ }^{2}$, Tomáš Scholz ${ }^{1,3}$, Oleg Ditrich $^{3}$ and Peter D. Olson ${ }^{2}$ \\ ${ }^{1}$ Institute of Parasitology, Biology Centre of the Academy of Sciences of the Czech Republic, České Budějovice, Czech Republic; \\ ${ }^{2}$ Department of Life Sciences, Natural History Museum, London, United Kingdom; \\ ${ }^{3}$ Faculty of Science, University of South Bohemia, České Budějovice, Czech Republic \\ * This paper is dedicated to Michael 'Mick’ David Brunskill Burt (1938-2014) whose recent passing represents a great loss to cestodology.
}

\begin{abstract}
Tapeworms of the order Spathebothriidea Wardle et McLeod, 1952 (Cestoda) are reviewed. Molecular data made it possible to assess, for the first time, the phylogenetic relationships of all genera and to confirm the validity of Bothrimonus Duvernoy, 1842, Diplocotyle Krabbe, 1874 and Didymobothrium Nybelin, 1922. A survey of all species considered to be valid is provided together with new data on egg and scolex morphology and surface ultrastructure (i.e. microtriches). The peculiar morphology of the members of this group, which is today represented by five effectively monotypic genera whose host associations and geographical distribution show little commonality, indicate that it is a relictual group that was once diverse and widespread. The order potentially represents the earliest branch of true tapeworms (i.e. Eucestoda) among extant forms.
\end{abstract}

Keywords: Eucestoda, taxonomy, scanning electron microscopy, 28S rDNA, 18S rDNA, ITS2, phylogenetic relationships, distribution

The order Spathebothriidea Wardle et McLeod, 1952 exhibits all of the hallmarks of a relictual group that was once diverse and widespread, but is today represented by a small number of refugial species whose host associations and geographical distribution show little commonality. Multiple lines of evidence suggest that the group is indeed ancient and potentially represents the earliest branch of true tapeworms (i.e. Eucestoda) among extant forms. Morphologically, they share features of both the eucestodes (including a hexacanth embryonic stage and the serial repetition of the reproductive organs) and the 'cestodarian' sister group Amphilinidea (in their utilisation of amphipod intermediate hosts, lack of external segmentation and a scolex lacking either bothrial or acetabulate holdfast structures).

Molecular phylogenetic analyses have also provided independent support for a basal position of the group (Olson and Caira 1999, Kodedová et al. 2000, Olson et al. 2001, 2008, Waeschenbach et al. 2007, 2012). Progenesis is common in the group (Sandeman and Burt 1972, Okaka 2000) and has been used as evidence of their 'primitive' position (Beveridge 2001), albeit this argument pre-supposes the original definitive (or only) host of the tapeworm ancestor to be an invertebrate. Geographically, they have a disjunctive distribution across the northern hemisphere (i.e. a circumboreal distribution), with each of the five described genera parasitising disparate groups of freshwater, euryhaline or marine fishes.

A total of 15 nominal species within five genera have been proposed, with the first species described as Taenia truncata by Pallas (1781) (see details in Caira et al. 2014). The taxonomy and systematics of the group has been reviewed by Nybelin (1922), Burt and Sandeman (1969), Gibson (1994) and Protasova and Roitman (1995). In this paper, we provide a survey of all species together with new data on scolex, egg and microthrix morphology. Variable regions of rDNA were characterised from newly collected material in order to test for intraspecific variation and to examine the interrelationships of the group. Sequence data were also characterised from formalin-fixed material of the sturgeon-hosted species Bothrimonus fallax Lühe, 1900, allowing us to test its taxonomic validity and phylogenetic affinities using data independent of morphology for the first time. 


\section{MATERIALS AND METHODS}

\section{Specimens examined}

The present study was based on morphological and molecular evaluations of specimens recently collected by the authors and their collaborators, as well as on historical collections deposited in the following museums: Göteborgs Naturhistoriska Museum, Göteborg, Sweden (GNM); Helminthological collection of the Institute of Parasitology, Czech Academy of Sciences, České Budějovice (IPCAS); Muséum National d'Histoire Naturelle, Paris, France (MNHN); Natural History Museum, London, UK (BMNH); and United States National Parasite Collection, Beltsville, MD, USA (USNPC).

\section{The following newly collected material was studied:}

(i) Cyathocephalus truncatus (Pallas, 1781): 10 specimens from Salmo trutta Linnaeus (Salmoniformes: Salmonidae), River Brenta, Italy $\left(45^{\circ} 07^{\prime} \mathrm{N} ; 12^{\circ} 02^{\prime} \mathrm{E}\right.$; collected by B. Dezfuli 27 July 1997 and February 2007; IPCAS C-13/1); 2 specimens from Coregonus lavaretus (Linnaeus) (Salmoniformes: Salmo-

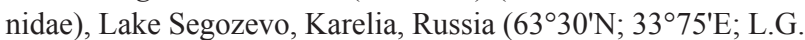
Poddubnaya, 17 July 2004; IPCAS TS-04/136, and on June 2005; IPCAS TS-06/9); pieces of both specimens were used for molecular study.

(ii) Diplocotyle olrikii Krabbe, 1874: 30 specimens from Myoxocephalus scorpius (Linnaeus) (Scorpaeniformes: Cottidae), Petunia Bay, Isfjorden, Svalbard Archipelago, Arctic Ocean $\left(78^{\circ} 68^{\prime} \mathrm{N}\right.$; $\left.16^{\circ} 45^{\prime} \mathrm{E}\right)$ (R. Kuchta and O. Ditrich, see details in Table 2; IPCAS C-333/4); 2 specimens sequenced, and Gymnocanthus tricuspis (Reinhardt) (Scorpaeniformes: Cottidae), from the same locality (R. Kuchta and O. Ditrich IPCAS C-333/5; two progenetic specimens from the body cavity of $M a-$ rinogammarus sp. (Amphipoda: Gammaridae), off St. Andrews, Scotland, UK $\left(56^{\circ} 21^{\prime} \mathrm{N} ; 2^{\circ} 48^{\prime} \mathrm{W}\right.$; P.D. Olson, R. Kuchta and J. Brabec, 5 April 2004, 1 infected out of 1673 examined amphipods; IPCAS C-645/1).

(iii) Spathebothrium simplex Linton, 1922: 2 specimens from Liparis fabricii Krøyer (Scorpaeniformes: Liparidae), Petunia Bay, Isfjorden, Svalbard Archipelago, Arctic Ocean $\left(78^{\circ} 68^{\prime} \mathrm{N}\right.$; $16^{\circ} 45^{\prime} \mathrm{E}$ ), (R. Kuchta and O. Ditrich 1 August 2008; IPCAS C-568); pieces of both specimens used for DNA sequencing; 1 specimen from Liparis atlanticus (Jordan et Evermann), off Rye Beach, New Hampshire, USA (42॰58'7"N; 7045'49"W; R. Kuchta, 10 April 2009).

The following museum material was studied:

(i) Bothrimonus fallax: 10 specimens from Acipenser nudiventris Lovetsky (Salmoniformes: Salmonidae), Caspian Sea, Russia (leg. Pilarcki; IPCAS C-382/1); 1 specimen Kulai (= Aygedzor, Tavush Province), Armenia (leg. E. Lönnberg; 22 May 1899; GNM 2524); 10 specimens from Acipenser stellatus Pallas, Agrakhanski Bay, Caspian Sea, Russia (leg. B. Kuperman; 29 April 1966; IPCAS C-382/2); 2 specimens from A. stellatus, off Dagestan, Caspian Sea, Russia (IPCAS C-382/2); 1 specimen from Huso huso (Linnaeus), Kizil-Aga, Turkmenistan (leg. B. Kuperman; 2 June 1962; IPCAS C-382/3) (all hosts Acipenseriformes: Acipenseridae).

(ii) Cyathocephalus truncatus: 2 specimens from Coregonus lavaretus, Lake Baikal, Russia (leg. O. Rusinek; 20 July 1997; IPCAS C-13/3); 10 specimens from Salmo trutta, River Tirino, Italy (23 March 1977; IPCAS C-13/1); 1 specimen from Gam- marus italicus Goedmakers et Pinkster (Amphipoda: Gammaridae), Tirino River, Italy (27 April 1977; IPCAS C-13/1).

(iii) Diplocotyle olrikii: 2 specimens from Oncorhynchus gorbuscha (Walbaum) (Salmoniformes: Salmonidae), Pacific Ocean, Canada (leg. M. Burt; BMNH 1982.10.1.24-26); 1 specimen from Salvelinus sp. (Salmoniformes: Salmonidae), Kamchatka Bay, Kamchatka, Russia (leg. B. Kuperman; 19 April 1966; IPCAS C-333/2); 10 specimens from Salvelinus alpinus (Linnaeus), Ottostrand, East Greenland (leg. H. Fleisher; $19 \mathrm{Au}-$ gust 1947; BMNH 1961.2.22.17-20 and 1963.10.7.7-50); 15 specimens from Salmo salar Linnaeus, Newfoundland, Canada (leg. M. Burt; BMNH 1982.9.20.144-169); 10 specimens from Salmo trutta, Osnes, R. Selfjort, Iceland (leg. R.E. Wauch; 5 July 1980; BMNH 1982.3.3.1-25); 1 specimen from Thymallus arcticus (Pallas) (Salmoniformes: Salmonidae), Chukotka, Far East, Russia (leg. B. Kuperman; 1962; IPCAS C-333/3); 2 specimens from Monoporeia affinis (Lindström) (Amphipoda: Pontoporeiidae) Tvarminne, Baltic Sea, Finland (leg. E.T. Valtonen; 5 August 1985; BMNH 1988.3.17.2-6).

(iv) Didymobothrium rudolphi (Monticelli, 1890): 1 specimen from Pegusa cadenati Chabanaud (Pleuronectiformes: Soelidae), off Cape Verde, Atlantic Ocean (leg. P. Chabanaud, 10 January 1952; MNHN bD 52); 4 specimens from Pegusa lascaris (Risso), off Banyuls-sur-Mer, Mediterranean Sea, France (leg. O. Nybelin; 11 October 1959; GNM 481); 4 specimens, off Plymouth, English Channel, UK (D. Gibson; May 1972; BMNH 1989.1.31.38-41); 10 specimens, off northern Portugal, Atlantic Ocean (J.M. Marques; 2003; BMNH 2006.10.4.9-20); 2 spec. from Solea solea (Linnaeus) (Pleuronectiformes: Soelidae), off Turkey, Mediterranean Sea (M.C. Oğuz; BMNH 1993.1.21.10; 1997.9.30.1).

\section{Morphological studies}

Tapeworms collected by the present authors were washed in saline and those for morphological studies, including scanning electron microscopical (SEM) observations and histology, were fixed with hot $4 \%$ formaldehyde solution. Additional specimens or parts of specimens were preserved in $96 \%$ molecular-grade ethanol for molecular study. Whole-mounted specimens were stained with Schuberg's hydrochloric carmine and mounted in Canada balsam. Cross-sections of the strobila (thickness $15 \mu \mathrm{m}$ ) were stained with haematoxylin-eosin, using standard histological techniques. Several scoleces and segments were prepared for SEM following the procedure outlined by Kuchta and Caira (2010). The microthrix terminology follows Chervy (2009). The development of the eggs liberated from the uterus of unstained specimens of $D$. olrikii and $S$. simplex using fine needles were placed in distilled water and observed under light microscopy. In a survey of the species, illustrations (line drawings) of individual taxa are not provided because they were presented in several taxonomic accounts, such as those of Nybelin (1922), Burt and Sandeman (1974), Gibson (1994), and Protasova and Roitman (1995). For comparison eggs of Amphilina foliacea (Rudolphi, 1819) from Acipenser ruthenus, Danube River, Slovakia (M. Oros; 20 April 2011; IPCAS C-44/1), were also studied using light microscopy (LM) and SEM.

\section{Molecular characterisation from fresh material}

Molecular ribosomal data were characterised from newly collected specimens of Cyathocephalus truncatus (2 spec. sequenced), Diplocotyle olrikii $(\mathrm{n}=8)$ and Spathebothrium sim- 
Table 1. New sequences of spathebothriideans used in phylogenetic analyses.

\begin{tabular}{lllll}
\hline $\begin{array}{l}\text { Access. No. } \\
\text { 28S rDNA/ITS2 }\end{array}$ & Coll. No. & Parasite & Host & Locality \\
\hline$*$ & TS 04/10 & Bothrimonus fallax & Acipenser nudiventris & Caspian Sea, Russia \\
KJ400369/ KJ400374 & TS 04/136 & Cyathocephalus truncatus & Coregonus lavaretus & Lake Segozevo, Russia \\
KJ400370/ KJ400375 & TS 06/9 & Cyathocephalus truncatus & Coregonus lavaretus & Lake Segozevo, Russia \\
KJ400366/ KJ400379 & TS 09/271 & Diplocotyle olrikii & Gymnocanthus tricuspis & Svalbard, Arctic Ocean \\
KJ400363 & TS 09/275 & Diplocotyle olrikii & Myoxocephalus scorpius & Svalbard, Arctic Ocean \\
KJ400367/ KJ400378 & TS 09/279 & Diplocotyle olrikii & Myoxocephalus scorpius & Svalbard, Arctic Ocean \\
KJ400368 & TS 09/280 & Diplocotyle olrikii & Gymnocanthus tricuspius & Svalbard, Arctic Ocean \\
KJ400361 & TS 09/282 & Diplocotyle olrikii & Myoxocephalus scorpius & Svalbard, Arctic Ocean \\
KJ400364 & TS 09/283 & Diplocotyle olrikii & Myoxocephalus scorpius & Svalbard, Arctic Ocean \\
KJ400362/ KJ400377 & TS 09/284 & Diplocotyle olrikii & Myoxocephalus scorpius & Svalbard, Arctic Ocean \\
KJ400365/ KJ400376 & AR3 & Diplocotyle olrikii & Myoxocephalus scorpius & Svalbard, Arctic Ocean \\
KJ400372/ KJ400373 & AR23 & Spathebothrium simplex & Liparis fabricii & Svalbard, Arctic Ocean \\
\hline
\end{tabular}

* partial 18S rDNA (see sequence on Fig. 25).

plex $(\mathrm{n}=2)$ (see Table 1). Following Marques et al. (2007), the D2 region of the $28 \mathrm{~S}$ rDNA gene ( $660 \mathrm{bps})$ was characterised for all specimens $(\mathrm{n}=12)$ and the ITS-2 region $(\sim 600 \mathrm{bps})$ for each of the specimens, except for replicates of $D$. olrikii that proved identical based on comparison of $28 \mathrm{~S}$ sequences $(\mathrm{n}=8)$ (Table 1). These data were combined with published 28S and ITS2 sequences of these three taxa as well as Didymobothrium rudolphii from the work of Marques et al. (2007). Attempts were also made to characterise the cytochrome $c$ oxidase subunit I gene, used for 'species barcoding' in many groups (especially arthropods and vertebrates), using a variety of primer combinations from Littlewood et al. (2008) and Moszczynska et al. (2009), but without success.

Ethanol in the samples was replaced by Tris-EDTA buffer through two rinses and genomic DNA extracted with a DNeasy kit (Qiagen, Venlo, Neatherlands) and a hand-held homogeniser fitted with sterile plastic pestles. PCR was performed using PuRe Taq Ready-To-Go beads (GE Healthcare, Little Chalfont, UK). The D1-D3 region of the $28 \mathrm{~S}$ was amplified using primers LSU5 and 1200R (Olson et al. 2001) and the ITS2 using primers ITS2.3S (GGT ACC GGT GGA TCA CGT GGC TAG TG) and ITS2.2 (CCT GGT TAG TTT CTT TTC CTC CGC). Cycling parameters were as follows: denaturation $\left(95^{\circ} \mathrm{C} / 5 \mathrm{~min}\right)$, amplification $\left(40\right.$ cycles $\left.95^{\circ} \mathrm{C} / 30 \mathrm{~s}, 52^{\circ} \mathrm{C} / 30 \mathrm{~s}, 72^{\circ} \mathrm{C} / 90 \mathrm{~s}\right)$, extension $\left(72{ }^{\circ} \mathrm{C} / 1 \mathrm{~min}\right)$. Products were visualised on agarose gels, purified using Qiagen spin columns and sequenced directly by Sanger sequencing. The $28 \mathrm{~S}$ products were sequenced using internal primers 300F and ECD2 (Olson et al. 2001), whereas the ITS2 products were sequenced using the PCR primer combinations.

Molecular characterisation of Bothrimonus fallax from formalin-fixed material

Only formalin-fixed museum specimens of Bothrimonus fallax were available for study despite prolonged efforts to obtain fresh material, especially from Iran (see Discussion). Attempts to extract gDNA were made from a range of samples from museum collections, all with unknown type of fixation, but presumed to have had prolonged exposure to formalin and possibly additional harmful chemicals such as industrial methylated ethanol. These samples were homogenised in $1 \mathrm{ml}$ of water using a Precellys 24 lysis and homogenisation machine (Bertin Technologies, Paris, France) with ceramic beads at $6500 \mathrm{rpm}$ for
$23 \mathrm{~s}$. Tissues were separated from the water and gDNA extracted using a QIAmp DNA FFPE tissue kit (Qiagen) specifically designed for formalin-fixed and paraffin-embedded samples.

A nested PCR approach was used in an attempt to amplify products from both the $28 \mathrm{~S}$ and $18 \mathrm{~S}$ rDNA genes. For both genes a large combination of primers was tried, targeting small ( $\sim 350 \mathrm{bp})$ fragments from larger $(\sim 1000 \mathrm{bp})$ initial PCR products (even when the initial products were not visible). However, this approach either failed to produce results or resulted in sequences amplified via nested PCR that proved to be contaminants (e.g. fungi). We therefore tried to design spathebothriidean-specific primers using the $18 \mathrm{~S}$ and $28 \mathrm{~S}$ alignments of Olson et al. (2008) to find priming regions that were putatively unique to spathebothriidean taxa (to avoid amplification of other organisms, including other tapeworms) and that would amplify very short ( 100-200 bp) fragments (to accommodate highly fragmented gDNA samples) of highly variable regions of the $18 \mathrm{~S}$ and 28S genes (e.g. 18S - V4, V7, V9).

Initial PCR amplification was done as above with PCR beads and $0.1-1 \mu 1$ of the PCR products was used directly for secondary, nested amplifications using a combination of spathebothridean-specific primers. The cycling profile for nested PCR was as above except that only 25 cycles were run and the extension time was reduced to $30 \mathrm{~s}$. Gradient PCR was also used to test a range of annealing temperatures between $55^{\circ} \mathrm{C}$ and $60^{\circ} \mathrm{C}$. Because of the small fragment size, products were visualised on $3.5 \%$ agarose gels and cleaned using a Microcon YM30 centrifugal filter device prior to Sanger sequencing as described above.

\section{Phylogenetic analyses}

All bioinformatic and phylogenetic analyses were conducted using Geneious ver. 6.1.6 (Biomatters, Auckland, New Zealand; available from http://www.geneious.com). The closely related 'cestodarian' (Amphilinidea and Gyrocotylidea) and eucestode groups (Caryophyllidea) were considered as outgroups (Olson et al. 2001, 2008), but representative sequences showed little homology for the highly variable regions of 28S, 18 S and ITS-2 sequenced. One exception was the 28S D1-D3 region of Amphilina foliacea that was similar in length and composition to the spathebothriidean sequences and was thus used as an outgroup in these analyses. Based on these results, Spathebothrium simplex was used as a functional outgroup for analyses of the ITS-2, whereas results of the $18 \mathrm{~S}$ analyses based on only 
$100 \mathrm{bps}$ of data were left unrooted. A nucleotide substitution model was chosen using MrModelTest (ver. 2.; Nylander 2008) and applied to both maximum likelihood and Bayesian analyses, and parsimony analyses were run with all changes given equal weight.

\section{RESULTS}

\section{Taxonomic account}

Several revisions of spathebothriidean tapeworms have been carried out (Gibson 1994, Protasova and Roitman 1995), but only one study (Burt and Sandeman 1969) synonymised the genera Diplocotyle Krabbe, 1874 and Didymobothrium Nybelin, 1922 with Bothrimonus Duvernoy, 1842 . The validity of these genera was tested by morphological and molecular approach. The following species of the Spathebothriidea are considered to be valid based on a critical revision of published data combined with new data obtained in this study (all nominal taxa are available in the Global Cestode Database; Caira et al. 2014):

Family Acrobothriidae Olsson, 1872

Bothrimonus Duvernoy, 1842

Bothrimonus sturionis Duvernoy, 1842 - type species

Synonym: Disymphytobothrium paradoxum Diesing, 1854.

Type and only host: Acipenser oxyrhynchus Mitchill (Acipenseriformes: Acipenseridae).

Ty p e loc ality: Wabasch River (near the mouth to the Ohio River), Mississippi basin, Ohio, USA.

Distribution: USA.

Morphological description: Duvernoy (1842), Protasova and Roitman (1995).

Remarks. Bothrimonus sturionis, the type species of the genus, was described from a single specimen collected from Acipenser oxyrhynchus in the USA by M. Lesueur in 1835. No other record of the species from sturgeons in North America exists and thus Markevich (1951) questioned the validity of the species, whereas Skryabina (1974) considered it to be a valid taxon. We concur with Protasova and Roitman (1995) that the misidentification of Diplocotyle olrikii from an atypical host is the most probable explanation for the record, but this assumption cannot be confirmed because the type material of B. sturionis is not known to be extant (J.-L. Justine, MNHN, Paris, France - pers. comm.). Therefore, the species is tentatively retained as valid in the present account.

Bothrimonus fallax Lühe, 1900

Figs. 1, 3, 11, 19

Synonyms: Bothrimonus pachycephalus Linstow, 1904; Bothrimonus caspicus Cholodkovsky, 1914.

Type host: Acipenser ruthenus Linnaeus (Acipenseriformes: Acipenseridae).

Additional hosts: Acipenser gueldenstaedtii Brandt et Ratzeburg, A. nudiventris Lovetsky, A. persicus Borodin,
A. stellatus Pallas, A. sturio Linnaeus, Huso huso (Linnaeus).

First intermediate host: Freshwater gammarid $D i$ kerogammarus haematobaphes (Eichwald) (Amphipoda: Gammaroidea) (Sudarikov and Kurochkin 1964).

Type locality: Black Sea off Romania.

D istribution: Caspian Sea (off coasts of Azerbaijan, Iran, Kazakhstan, Russia and Turkmenistan), River Kura (Azerbaijan) and River Volga (Russia), also sporadically reported from the Black Sea.

Morphological descriptions: Nybelin (1922), Protasova and Roitman (1995).

Selected references: Lühe (1900), Cholodkovsky (1914), Nybelin (1922), Dogiel and Bychowsky (1938), Izyumova (1977), Sattari (2002), Mamedova (2005), Sattari and Mokhayer (2005), Noei (2010, 2011)

Remarks. Bothrimonus fallax was described by Lühe (1900) from specimens collected by Volz (1899) off the Black Sea coast off Romania, but all other records are from the Caspian Sea (Nybelin 1922, Protasova and Roitman 1995, present study), especially from its southern parts off Azerbaijan and Iran (Mamedova 2005, Sattari and Mokhayer 2005, Noei 2010, 2011). The prevalence of B. fallax in sturgeons is usually low, only about $5 \%$ (Sattari and Mokhayer 2005, Noei 2011), with the highest prevalence up to $14 \%$ in summer (Sattari 2002).

Nybelin (1922) and Protasova and Roitman (1995) provided the most detailed morphological descriptions of the species, which is characterised by the presence of an incomplete septum dividing the lumen of the funnellike scolex (Fig. 11) and genital pores that alternate, being located either on the dorsal or on the ventral side of the body. The life cycle has not been fully elucidated, but the freshwater gammarid Dikerogammarus haemobaphes has been identified as an intermediate host by Sudarikov and Kurochkin (1964).

Bothrimonus fallax is mostly found in sturgeons during their marine life phase, but it has been found twice in sturgeons migrating upstream as far as $450 \mathrm{~km}$ from the coast (Mikailov 1963, Ivanov 1968). Some authors (e.g. Markov et al. 1967, Bauer et al. 2002) have reported younger fish to be more heavily infected than older ones, whereas others found young sturgeons to be entirely uninfected (e.g. Skryabina 1974, Sattari 2002).

\section{Cyathocephalus Kessler, 1868}

Cyathocephalus truncatus (Pallas, 1781) Kessler, 1868 type and only species Figs. 6, 7, 9, 14, 20

Synonyms: Taenia truncata Pallas, 1781; Vermis esocis lucii Rudolphi, 1810; Dubium esocis lucii Rudolphi, 1819; Cephalocotylum esocis lucii Diesing, 1850; Cyathocephalus tuba (von Siebold, 1837) Bairol, 1853; Acrobothrium typicum Olsson, 1872; Cyathocephalus truncata Southwell, 1913; Cyathocephalus americanus Cooper, 1917.

Type host: Esox lucius Linnaeus (Esociformes: Esocidae). 

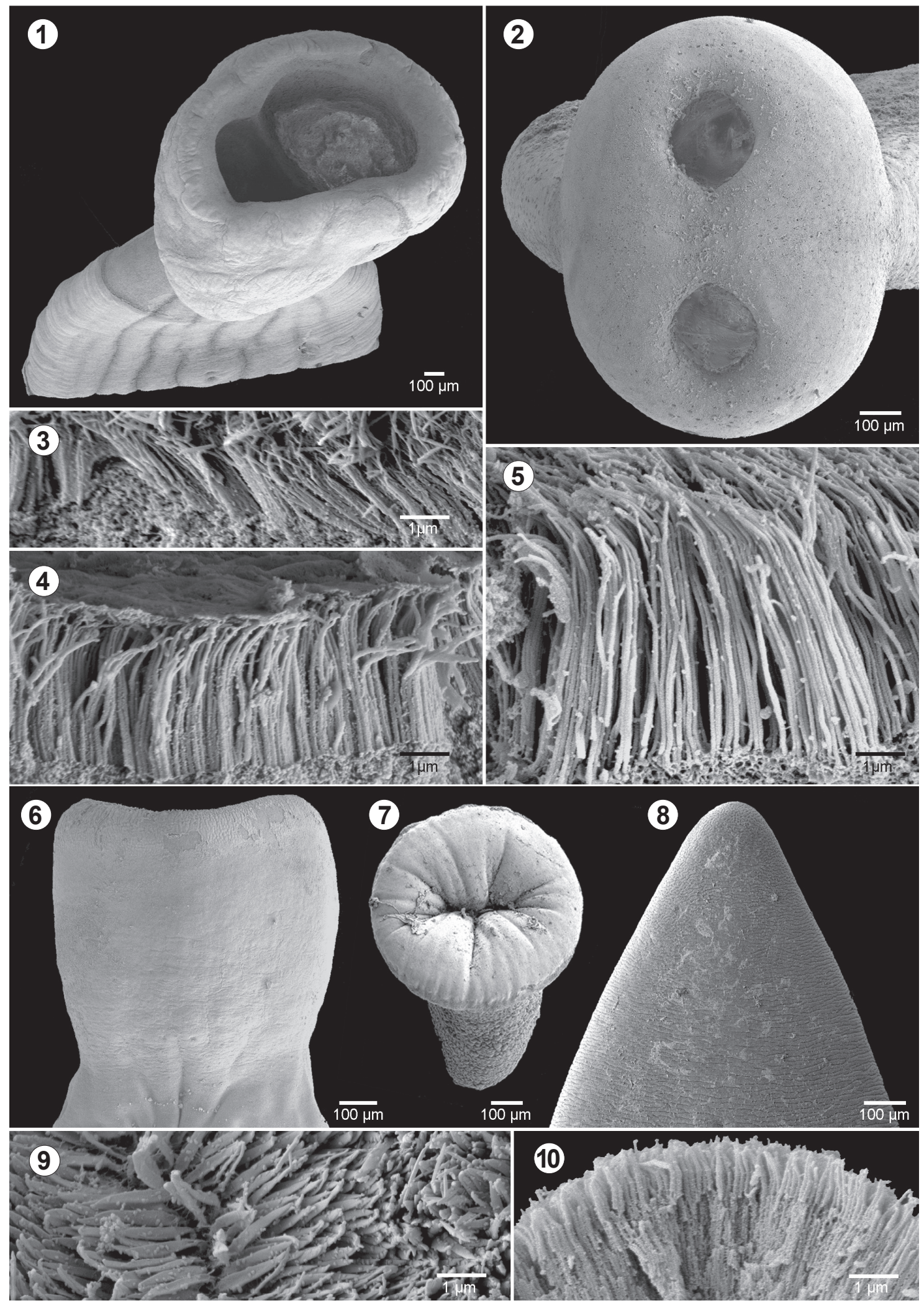

Figs. 1-10. Spathebothriidean cestodes; scanning electron micrographs. Figs. 1, 3. Bothrimonus fallax from Acipenser nudiventris, Caspian Sea, Russia. Figs. 2, 5. Diplocotyle olrikii from Myoxocephalus scorpius, Petunia Bay, Svalbard, Arctic Ocean. Fig. 4. Diplocotyle olrikii from Marinogammarus sp., off St. Andrews, Scotland, UK. Figs. 6, 7, 9. Cyathocephalus truncatus from Salmo trutta, Brenta River, Italy. Figs. 8, 10. Spathebothrium simplex from Liparis fabricii, Petunia Bay, Svalbard, Arctic Ocean. Scolex in apical view $(1,2,7)$ and dorsoventral $(6,8)$. Surface of the scolex covered with capilliform filitriches, magnification $10000 \times(3-5,9,10)$. 

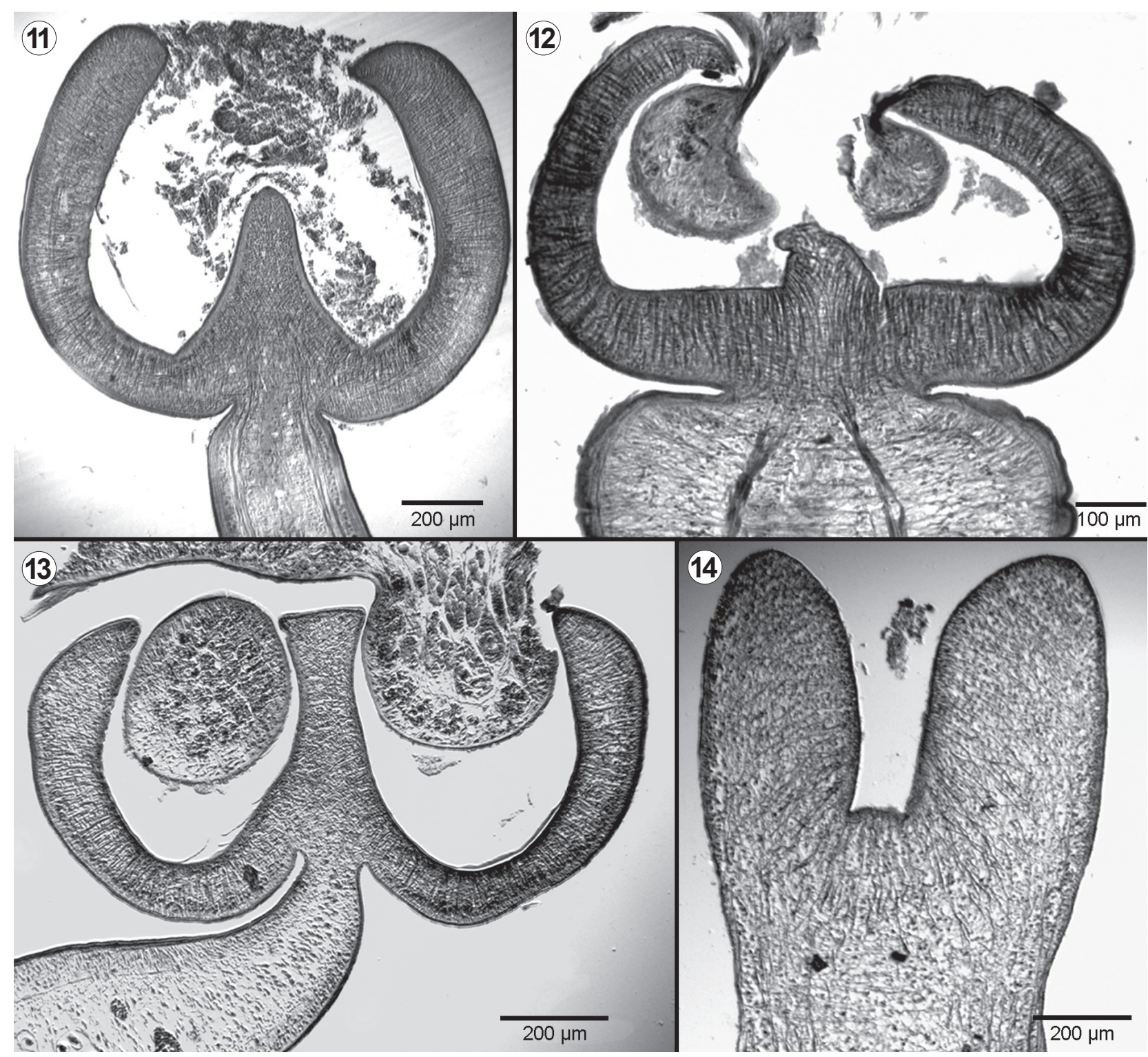

Figs. 11-14. Spathebothriidean cestodes; photomicrographs of histological sections through the scolex. Fig. 11. Bothrimonus fallax from Acipenser nudiventris, Caspian Sea, Russia. Fig. 12. Didymobothrium rudolphii from Pegusa lascaris, off Banyuls-surMer, Mediterranean Sea, France. Fig. 13. Diplocotyle olrikii from Myoxocephalus scorpius, Petunia Bay, Svalbard, Arctic Ocean. Fig. 14. Cyathocephalus truncatus from Salmo trutta, River Brenta, Italy.

Additional hosts: Mostly salmonids and coregonids, such as species of Salmo Linnaeus, Salvelinus Richardson and Coregonus Linnaeus (see Protasova and Roitman 1995 for a comprehensive list of hosts).

First intermediate hosts: Freshwater gammarids (Amphipoda: Gammaroidea), e.g. species of Echinogammarus Stebbing, Eulimnogammarus Bazikalova, Gammarus Linnaeus, Gmelinoides Bazikalova, Pallasea Sars, Poekilogammarus Stebbing, Pontogammarus Sowinsky, and Pontoporeia Krøyer. Amin (1978) reported a plerocercoid of C. truncatus from Mysis relicta Lovén (Amphipoda: Mysidae) (see Protasova and Roitman 1995 for a more exhaustive list).

Type locality: St. Petersburg, Russia.
D istribution: Europe (Bosna and Herzegovina, Estonia, Finland, France, Germany, Italy, Lithuania, Macedonia, Norway, Poland, Serbia, Slovakia, Sweden, Switzerland, UK, Ukraine), Asia (Mongolia, Russia - Far East, Karelia, Kola Peninsula, Krasnodar Region, Lakes Ladoga and Onega, Rybinsk Reservoir, Siberia) and North America (Canada Alberta, British Columbia, Manitoba, Newfoundland, Northwest Territories, Ontario, Quebec; Greenland; USA - Alaska, Michigan, Montana, Oregon, Wisconsin).

Morphological descriptions: Nybelin (1922), Protasova and Roitman (1995).

Selected references: Cooper (1918), Nybelin (1922), Protasova and Roitman (1995). 

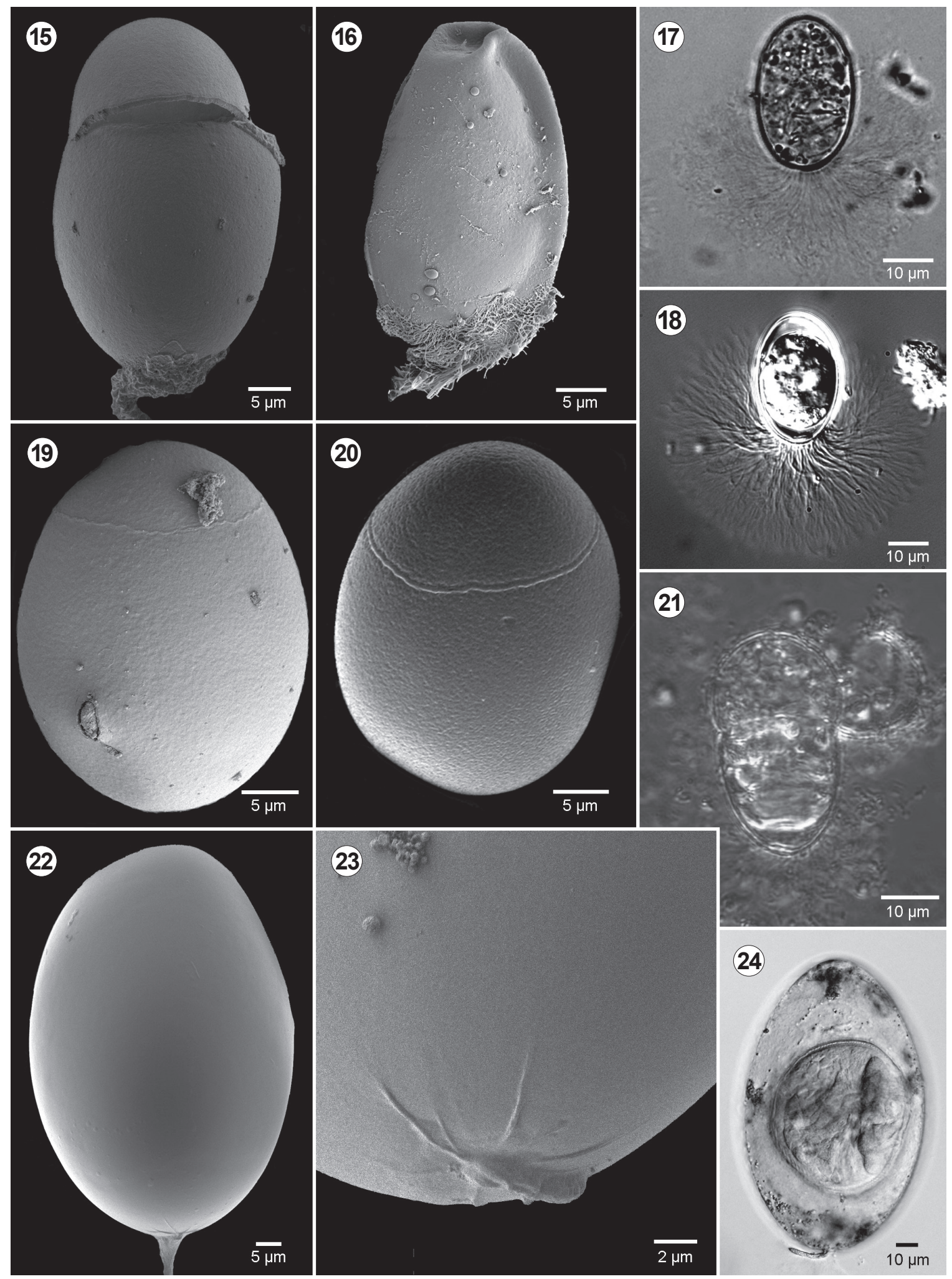

Figs. 15-24. The eggs of spathebothriidean and amphilinidean cestodes; scanning electron micrographs and photomicrographs. Fig. 15. Diplocotyle olrikii from Myoxocephalus scorpius, Petunia Bay, Svalbard, Arctic Ocean. Fig. 16. Spathebothrium simplex from Liparis fabricii, Petunia Bay, Svalbard, Arctic Ocean. Fig. 17. Diplocotyle olrikii from Marinogammarus sp., off St. Andrews, Scotland, UK. Figs. 18, 21. Spathebothrium simplex from Liparis atlanticus, off Rye Beach, New Hampshire, USA. Hatching of coracidium (21). Fig. 19. Bothrimonus fallax from Acipenser nudiventris, Caspian Sea, Russia. Fig. 20. Cyathocephalus truncatus from Coregonus lavaretus, Lake Segozero, Karelia, Russia; Figs. 22-24. Amphilina foliacea (Amphilinidea) from Acipenser ruthenus, River Danube, Slovakia. 
Remarks. Cyathocephalus truncatus is the most common spathebothriidean, with prevalence up to $80-90 \%$ and intensity up to 80 parasites per fish (Dechtiar and Loftus 1965). It infects a wide spectrum of freshwater fish, especially salmonids and coregonids, but has also been reported from unrelated fish such as sturgeons (Acipenser baerii Brandt, A. ruthenus Linnaeus and $A$. sturio) in Europe and Asia (Skryabina 1974). The species is unique among spathebothriideans in its possession of a funnelshaped apical organ without a septum.

Plerocercoids of $C$. truncatus may reach maturity in the intermediate host (gammarid amphipods). Progenetic, i.e. egg-bearing, plerocercoids were found in the body cavity of Gammarus pulex after 24 days of development at $25^{\circ} \mathrm{C}$ (Okaka 2000). The tapeworm has been reported as a pathogen of fish, which may retard the growth of its host (Wiśniewski 1932, Vik 1958) or even cause the mass mortality of trout (Huitfeldt-Kaas 1927). It has been found that gammarids infected with $C$. truncatus were more susceptible to predation by alpine charr, Salvelinus alpinus (Linnaeus), than non-infected gammarids, probably because of parasite-induced alterations in behaviour or visibility (Knudsen et al. 2001).

Didymobothrium Nybelin, 1922

Didymobothrium rudolphii (Monticelli, 1890) Nybelin, 1922 - type and only species Fig. 12

Synonyms: Cestoideum paradoxum Rudolphi, 1819; Cephalocotyleum soleae Zschokke, 1887; Cyathocephalus catinatus Riggenbach, 1898.

Type host: Not explicitly mentioned in the original description, but Solea solea (Linnaeus) (Pleuronectiformes: Soleidae) was mentioned first in the original description.

Additional hosts: Pegusa cadenati Chabanaud (new host), P. impar (Bennett), P. lascaris (Risso), Solea senegalensis Kaup (all Pleuronectiformes: Soleidae).

Type locality: Mediterranean Sea, off Naples, Italy.

Distribution: Off Atlantic coasts of Europe and Africa $\left(14-50^{\circ} \mathrm{N}\right.$, with the northernmost record from off Playmouth, UK and the southernmost record from off Cape Verde) and Mediterranean Sea - off coasts of Europe (France, Greece, Italy, Portugal, Spain, Turkey), off coast of Africa (Algeria).

Selected references: Orecchia et al. (1985), Renaud and Gabrion (1988), Álvarez et al. (2002), Marques and Cabral (2007), Marques et al. (2007), Oguz and Bray (2008).

Remarks. This species is a typical parasite of flatfishes of the family Soleidae. Its distribution is limited to the Atlantic and Mediterranean coasts of Europe and Africa (no reliable record from northern Europe or North America is available). Papoutsoglou (1976) and Sanmartín Durán et al. (1989) reported D. rudolphii from flatfishes of the family Scophthalmidae, namely Lepidorhombus boscii (Risso) and L. whiffiagonis (Walbaum), but these records are doubtful and need verification.
Marques et al. (2007) provided new morphological and molecular data for D. rudolphii from the sand sole P. lascaris collected off the Atlantic coast of Portugal. Based on analyses of $28 \mathrm{~S}$ and ITS2, these authors detected two cryptic species, differing in their gene sequences and the seasonal pattern of occurrence north to south along the Portuguese coast. Renaud and Gabrion (1988) also reported the occurrence of cryptic species of D. rudolphii in the Mediterranean (which they referred to as Bothrimonus nylandicus) based on allozyme data. However, multivariate analysis of 20 morphological characters could only show one form to be more slender and elongate than the other with no discrete or consistent character differences found that could reliably distinguish individuals (Marques et al. 2007). Thus, neither Renaud and Gabrion (1988) nor Marques et al. (2007) chose to formally describe and name a new species, and the genus remains monotypic.

Recently, several ultrastructural studies on D. rudolphii have been published, with the main focus being on the spermiogenesis, vitellogenesis and the fine morphology of the ovary and eggs (Poddubnaya et al. 2007, Bruňanská and Poddubnaya 2010, Swiderski et al. 2010). The ultrastructural features support a view of the close relationships between the Spathebothriidea and the Diphyllobothriidea and the basal position of the Spathebothriidea within the Eucestoda. Two parallel rows of cortical microtubules were reported from the proximal part of the two-axoneme region of the spermatozoon for the first time in a eucestode (Bruňanská and Poddubnaya 2010). The comparative data demonstrate that vitelline material has unique features that may differ in species of three spathebothriidean genera and may be used for the recognition of separate taxa (Poddubnaya et al. 2006, 2007, Bruňanská and Poddubnaya 2010, Swiderski et al. 2010).

Diplocotyle Krabbe, 1874

Diplocotyle olrikii Krabbe, 1874 - type and only species Figs. 2, 4, 5, 13, 15, 17

Synonyms: Bothrimonus nylandicus Schneider, 1902; Diplocotyle cohaerens Linstow, 1903; Bothrimonus intermedius Cooper, 1917.

Type host: Salvelinus alpinus (as Salmo carpio Linnaeus - corrected by Zhukov 1963) (Salmoniformes: Salmonidae).

Additional hosts: This species has been reported from almost 50 species from 14 families (see Protasova and Roitman 1995), the most common being species of salmonids (Salmonidae), righteye flounders (Pleuronectidae) and scorpionfish (Scorpaenidae).

First intermediate hosts: Marine and estuarine gammarid amphipods (Amphipoda: Gammaroidea), e.g. species of Anonyx Krøyer, Dogielinotus Gurjanova, Eogammarus Birstein, Gammarus Fabricius, Marinogammarus Sexton et Spooner, Monoporeia Bousfield, Psammonyx Bousfield and Spinulogammarus Tzvetkova (listed alphabetically; see 
Table 2. Prevalence of Diplocotyle olrikii Krabbe, 1874 in fishes in Petunia Bay, Svalbard.

\begin{tabular}{|c|c|c|c|c|c|c|c|}
\hline Sampling dates & $\begin{array}{l}2008 \\
\text { 20. } 7 .-10.8 .\end{array}$ & $\begin{array}{c}2009 \\
25.7 .-5.8\end{array}$ & $\begin{array}{c}2010 \\
10.8 .-10.9\end{array}$ & $\begin{array}{l}2011 \\
\text { 10. } 7 .-10.8 .\end{array}$ & $\begin{array}{c}2012 \\
\text { 1. } 7 .-15.7 .\end{array}$ & $\begin{array}{c}2013 \\
\text { 7. } 8 .-25.8 .\end{array}$ & Total \\
\hline Fish host & \multicolumn{7}{|c|}{ Myoxocephalus scorpius } \\
\hline No. examined & 10 & 96 & 145 & 92 & 116 & 66 & 525 \\
\hline Prevalence $(\%)$ & 30 & 7 & 6 & 14 & 12 & 3 & 6.1 \\
\hline Fish host & \multicolumn{7}{|c|}{ Gymnocanthus tricuspis } \\
\hline No. examined & 0 & 31 & 73 & 20 & 20 & 21 & 165 \\
\hline Prevalence $(\%)$ & 0 & 3 & 14 & 15 & 5 & 0 & 9.9 \\
\hline
\end{tabular}

Protasova and Roitman 1995 for species list).

Type locality: Greenland (probably inland waters, but not specified in the original description).

Distribution: Circumboreal, i.e. arctic and subarctic brackish coastal water north of $40^{\circ} \mathrm{N}$ : Atlantic Ocean, off Europe (Finland, France, Germany, Island, Lithuania, Norway, Russia, Sweden, UK), Pacific Ocean, off Asia (Russia) and off North America (Canada, USA - Alaska).

Selected references: Burt and Sandeman (1969), Sandeman and Burt (1972), Protasova and Roitman (1995), Desdevises et al. (1998).

Remarks. This species was described from Salvelinus alpinus from Greenland (Krabbe 1874). It is a relatively common parasite of a wide spectrum of teleost fish, with salmonid and scorpaenid fish probably being the most suitable definitive hosts. Records from some fish hosts, such as eels [Anguilla rostrata (Lesueur) - Anguilliformes] and capelin [Mallotus villosus (Müller) - Osmeriformes], need verification and may represent accidental infections, as suggested by their very low prevalence (Protasova and Roitman 1995).

The species has a circumboreal distribution and is always distributed close to the coast in brackish water; no reliable records from fish taken far from the coast are known (Sandeman and Burt 1972). Several authors observed seasonality in the occurrence of adults in fish, with the highest prevalence being in summer, i.e. from June to August, with almost no infection being recorded in winter (Sandeman and Burt 1972, Haldorson 1984, Bouillon and Dempson 1989, present study). Examination of large numbers of two fish species, Myoxocephalus scorpius (Linnaeus) (525 specimens examined) and Gymnocanthus tricuspis (Reinhardt) (165 specimens; both Scorpaeniformes), from off Svalbard during six consecutive summer seasons (2008-2013) showed conspicuous fluctuations in the prevalence values between individual years, from 0 to $15 \%$ in G. tricuspis and 3 to $30 \%$ in M. scorpius, and a tendency for prevalence to decline from July to September was also observed (Table 2).

Plerocercoids were reported in gammarids between February and April in Scotland by Sandeman and Burt (1972) and present data, but Protasova et al. (2010) reported infections in amphipods from Sea of Okhotsk all year round. The prevalence of infection in gammarids is usually as low as about 0.1\% (Sandeman and Burt 1972, present study), but Protasova et al. (2010) reported as much as $14 \%$ of amphipods infected.

\section{Spathebothriidae Yamaguti, 1934}

Spathebothrium Linton, 1922

Spathebothrium simplex Linton, 1922 - type and only species

Figs. 8, 10, 16, 18, 21

Type host: Liparis liparis (Linnaeus) (Scorpaeniformes: Liparidae).

Additional hosts: Careproctus roseofuscus Gilbert et Burke, Crystallias matsushimae Jordan et Snyder, Liparis atlanticus (Jordan et Evermann), L. callyodon (Pallas), L. coheni Able, L. fabricii Krøyer (new host record), L. fucensis Gilbert, L. gibbus Bean (Scorpaeniformes: Liparidae).

First intermediate hosts: Marine gammarids Locustogammarus locustoides (Brandt) and Megamoera dentate Bate (Amphipoda: Gammaroidea) - (Protasova et al. 2010).

Type locality: Woods Hole, Massachusetts, USA, Atlantic Ocean (collected in 1904-1905).

D is tribution: Arctic coastal marine waters, north of $35^{\circ} \mathrm{N}$ : North Atlantic Ocean (off Canada, USA), Arctic Sea (off Norway - Svalbard [new geographical record], Russia) and North Pacific Ocean (off Japan, USA - California and Washington, Russia - Chukotka, Sea of Okhotsk).

References: Linton (1922, 1941), Yamaguti (1934), Hart and Guberlet (1936), Polyanskii (1955), Zhukov (1963), Munson (1974), Linkletter (1977), Nahhas and Krupin (1977), Muzzall (1980), Appy and Burt (1982), Machida and Araki (1992, 1994), McDonald and Margolis (1995), Hansson (1998), Protasova et al. (2010).

Remarks. Spathebothrium simplex is a specific parasite of liparid fishes and have a circumboreal distribution. Detailed morphological descriptions were provided by Linton (1922) and Hart and Guberlet (1936). The parasite has also been reported, probably accidentally, from gadids (Gadidae) and eelpouts (Zoarcidae) (Linton 1941, Appy and Burt 1982, Machida and Araki 1992).

Plerocercoids of $S$. simplex have been found recently by Protasova et al. (2010) in two species of amphipods from the Sea of Okhotsk with a high prevalence (25\%). The prevalence of infection in fish hosts may reach up to $75-100 \%$, whereas the intensity of infection is usually only about two worms per fish (Munson 1974, Nahhas and Krupin 1977, Muzzall 1980, present study). 
Table 3. Morphology of the eggs of spathebothriidean cestodes.

\begin{tabular}{lcccl}
\hline Species & Habitat & Filaments & Formation of oncosphere & Reference \\
\hline Bothrimonus fallax & freshwater & absent & unknown & present study \\
Cyathocephalus truncatus & freshwater & absent & 30 days & Okaka (1989) \\
Didymobothrium rudolphii & marine & present & unknown & Marques et al. (2007) \\
Diplocotyle olrikii & marine & present & 5 days & Sanderman and Burt (1972), present study \\
Spathebothrium simplex & marine & present & 8 days & present study \\
\hline
\end{tabular}

\section{Morphology of attachment organs}

The present study, based on the evaluation of new and museum material, made it possible to provide new data on the scolex morphology of five species of the order, including information from scanning electron micrographs and histological sections. Four scolex conditions can be recognised in individual genera:

(1) Anterior end of the body not differentiated - Spathebothrium simplex (Fig. 8).

(2) Single funnel-shaped organ - Cyathocephalus truncatus (Figs. 6, 7, 14).

(3) Forwardly directed sucker-like attachment organ with lumina completely separated internally by median septum - Didymobothrium rudolphii (Fig. 12; fig. 3A-B in Marques et al. 2007) and Diplocotyle olrikii (Figs. 2, 13).

(4) Forwardly directed sucker-like attachment organ with lumina completely fused and with only rudimentary septum at base - Bothrimonus fallax (Figs. 1, 11).

The scolex of spathebothriideans is uniformly covered by filitriches. Capilliform filitriches were observed using SEM for the first time on both Bothimonus fallax (although only material of poor-quality was available; length of filitriches $\sim 2 \mu \mathrm{m}$ ) and Spathebothrium simplex (length up to $6 \mu \mathrm{m}$ ), and also on both Diplocotyle olrikii (length up to $10 \mu \mathrm{m}$ ) and Cyathocephalus truncatus (Figs. 3-5, $9,10)$.

\section{Egg morphology}

Light and scanning electron microscopical observation of eggs liberated from the uterus of freshly collected Diplocotyle olrikii and Spathebothrium simplex and museum specimens of Bothrimonus fallax, Cyathocephalus truncatus and Didymobothrium rudolphii enabled us to present new data on egg morphology; these are summarised in Table 3. All spathebothriidean eggs have a large operculum and the surface is smooth or slightly roughened (Figs. 15-21). In addition, the eggs of Amphilina foliacea from Acipenser ruthenus were observed using SEM for comparison. Only a single polar filament was observed and an operculum is absent (Figs. 22-24).

\section{Phylogenetic analyses}

No differences in the sequences of any gene was found among individuals of the same species (see Discussion), and molecular data strongly supported the monophyly of each genus. Interrelationships of the genera (except for Bothrimonus) based on 28S rDNA (Fig. 25A) supported Spathebothrium as the most basal taxon, followed by Diplocotyle, and a sister relationship between Cyathocephalus and the two genotypes of Didymobothrium (see Marques et al. 2007). ITS-2 analyses (Fig. 25B), which used Spathebothrium as a functional outgroup, supported the same arrangement of (Diplocotyle (Cyathocephalus + Didymobothrium)). However, neither data partition strongly resolved the interrelationships between these genera, and comparison with outgroup sequences highlighted little homology between the tapeworm orders within these highly variable regions of rDNA.

\section{Molecular characterisation and phylogenetic affinities of Bothrimonus fallax}

Extraction of usable gDNA from formalin-fixed, 'historical' museum samples of Bothrimonus fallax (and other spathebothriidean species) proved almost impossible, even when attempting to amplify high-copy genes such as rDNA. Only a single, $\sim 150$ bp $18 \mathrm{~S}$ product was amplified from one sample of B. fallax (from Acipenser nudiventris, Caspian Sea, Russia) via nested PCR using putatively spathebothriidean-specific primers Spath18S_1470F (GGTGGCGTTTCAGTGAGACTG) and Spath18S_1600R (GAACCCGGAAGTAAACGCT).

The validity of the sequence was examined by BLAST comparison after the removal of the priming regions (leaving $100 \mathrm{bps}$ of unique sequence) demonstrating that it was both unique among all known sequences, and most similar to the $18 \mathrm{~S}$ sequences of other spathebothriidean tapeworms. Pairwise comparisons showed it to be $92 \%$ similar to Cyathocephalus truncatus, $80 \%$ to Diplocotyle olrikii, $76 \%$ to Spathebothrium simplex and $69 \%$ to Didymobothrium rudolphii and an unrooted phylogeny (Fig. 25C) supported its placement as the sister genus to Cyathocephalus, thus rejecting the synonymy of the genera Bothrimonus, Didymobothrium and Diplocotyle by Burt and Sandeman (1969).

\section{DISCUSSION}

Morphology of attachment organs of cestodes is one of the key morphological characteristics that readily differentiate individual orders (Wardle and McLeod 1952, Schmidt 1986, Khalil et al. 1994). The most widely distributed forms of attachment organs are: 


\section{A $28 \mathrm{~S}$ rDNA $(\mathrm{GTR}+\mathrm{I})$}

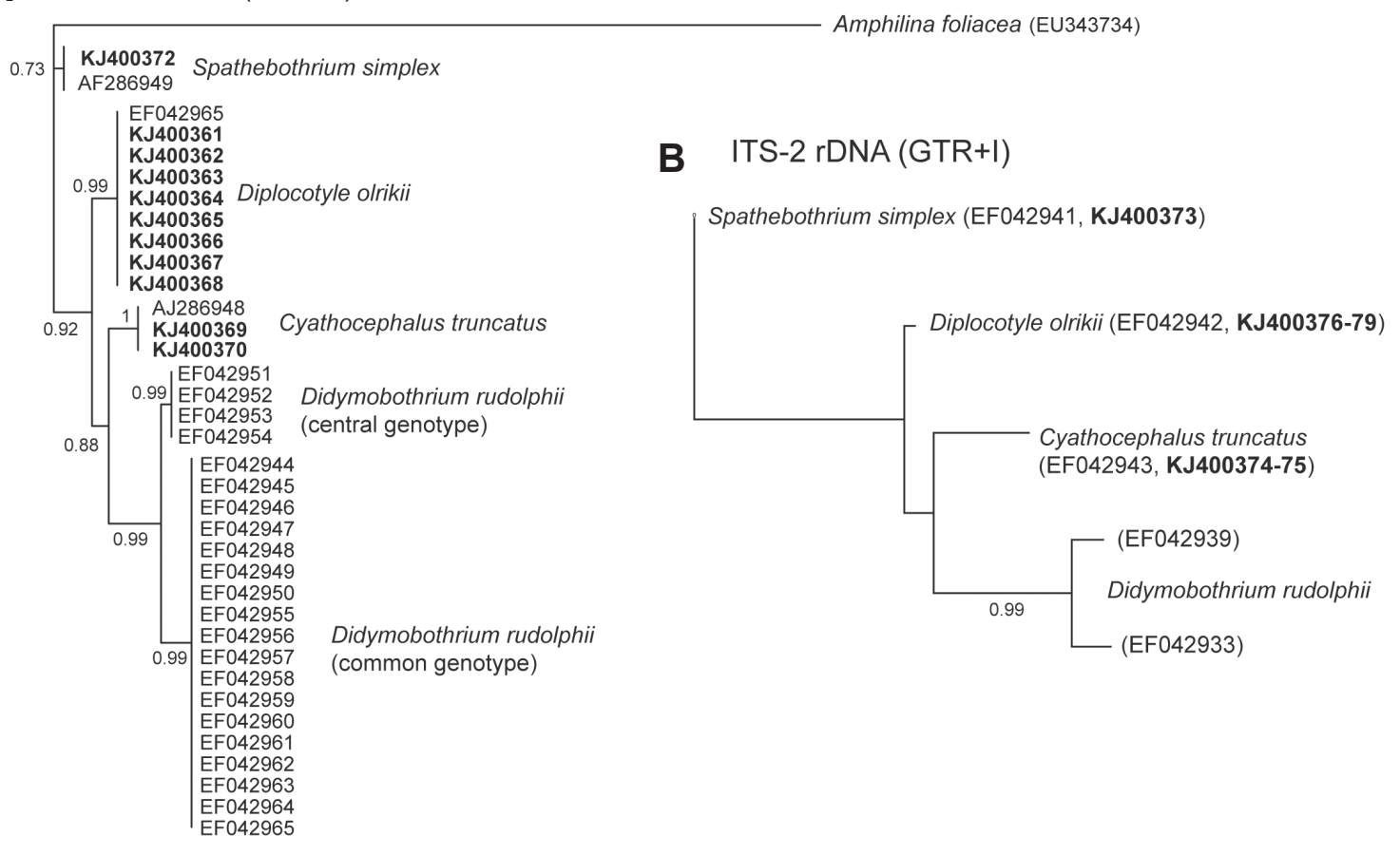

C $18 \mathrm{~S}$ rDNA (GTR)

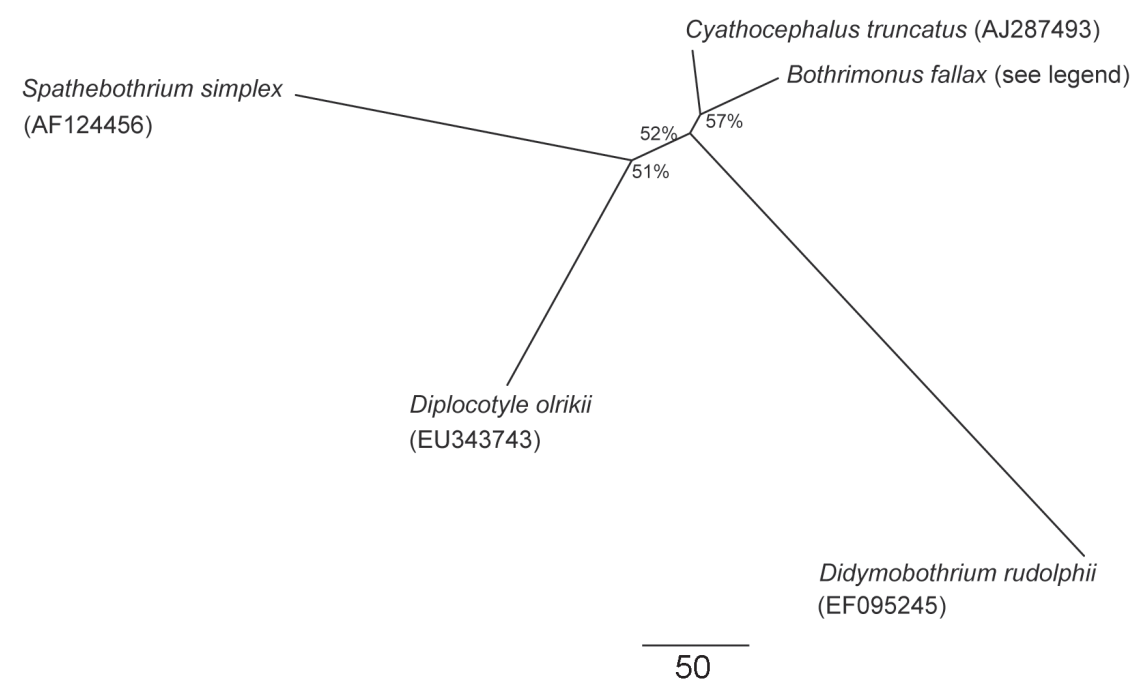

Fig. 25. Phylogenetic analyses of the Spathebothriidea. A - Bayesian inference tree based on partial 28S rDNA and rooted with Amphilina foliacea (Amphilinidea); posterior probabilities shown at nodes. B - Maximum likelihood topology based on ITS-2 data rooted with Spathebothrium simplex as a functional outgroup. C - Parsimony analysis of 18S rDNA (100 bps) with bootstrap support. Note the affinity of Bothrimonus fallax to Cyathocephalus truncatus, the only freshwater taxon in the group. Sequence accessions new to this study shown in bold. Partial sequence of $18 \mathrm{~S}$ of Bothrimonus fallax: CCCTATTTAGCTGTCTTCCTAGTGGGTGCATTGTTGATCGGTAGCTTTGTGTTGCTGGTTGGTGGTGTATCTGTTGGTTGATGGTTGGGGTGGTTGACCT.

(i) bothrium-like attachment structures, i.e. grooves of different shape, size and depth on the ventral and dorsal sides of the scolex that do not consist of radial muscular fibres, are not membrane-bound and are thus not delimited from the surrounding parenchyma (Wardle and McLeod 1952); these are present in lower tapeworm orders, such as the Caryophyllidea, Diphyllobothriidea, Haplobothriidea, Trypanorhyncha, Diphyllidea and Bothriocephalidea; and

(ii) acetabulate structures, i.e. bothridia and suckers (in both cases, the attachment organ is membrane-bound and thus clearly delimited from surrounding tissues). The latter structures are typical of higher groups of tapeworms, 


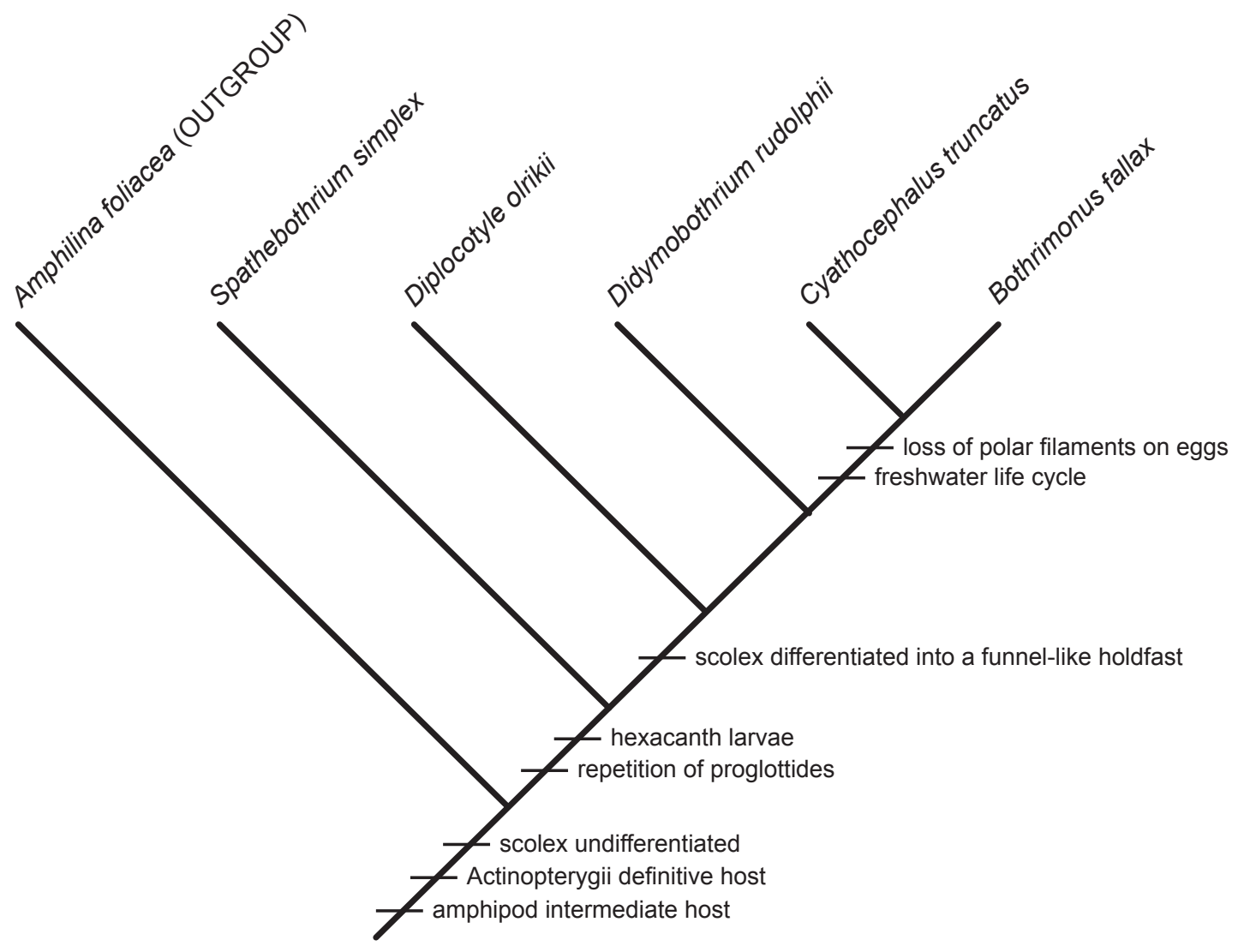

Fig. 26. Summary tree showing major synapomorphies of constituent groups of the Spathebothriidea.

such as the 'Tetraphyllidea-related' groups (including the Proteocephalidea), Tetrabothriidea and Cyclophyllidea (Olson et al. 2001).

In the Spathebothriidea, attachment organs open apically and thus differs markedly from those present in other cestode groups. These organs are paired or unpaired deep depressions that are separated completely or partly by a muscular septum. However, the absence of any differentiated structure at the anterior end of the most basal species, Spathebothrium simplex, indicates that a 'funnellike' scolex evolved in the group later, and diversified rather modestly among the four other species. None of the above conditions appear to have been shared in the species of any extant cestode groups. It is thus reasonable to assume that the existing bothrium-like and acetabulate attachment organs, present in other eucestodes, except for caryophyllideans, represent evolutionary innovations that appeared after the divergence of the spathebothriideans.

The unique morphology of the attachment organs present in spathebothriideans (see Burt and Sandeman 1974 for detailed data on the scolex morphology) indicates their independent origin in this group, rather than support the results of rDNA-based studies of Olson and Caira (1999), Kodedová et al. (2000), Olson et al. (2001, 2008) and Waeschenbach et al. (2007), who found support for the Spathebothriidea as the earliest branching 'true' tapeworms (Eucestoda), implying that the monozoic body plan of the Caryophyllidea represents a secondary loss of strobilation in the adult phase of their life cycle.

However, support for the early branching pattern of tapeworms using ribosomal data has been both weak and conflicting between the small (18S) and large (28S) rDNA genes, and the Caryophyllidea has been alternatively supported as the earliest branching group by at least some of the analyses in the same studies. Most recently, Waeschenbach et al. (2012) added large regions of mitochondrial, protein-coding sequences to the rDNA data, and found that whereas rDNA data supported a basal position of the Spathebothriidea, mitochondrial data supported the Caryophyllidea as the earliest lineage, followed by the Spathebothriidea. Although these authors concluded that the weight of the evidence supports a most basal position for the Caryophyllidea (Waeschenbach et al. 2012), a robust solution for the early branching pattern continues to be problematical.

Two types of filitriches have been observed on the scolex of Cyathocephalus truncatus by Levron et al. (2008): small acicular filitriches up to $3 \mu \mathrm{m}$ long and large capilliform filitriches measuring up to $10 \mu \mathrm{m}$ in length. In Diplocotyle olrikii, Burt and Sandeman (1974) reported microtriches up to $4 \mu \mathrm{m}$ long in plerocercoids from gammarids and adults from fish. In the same species, much 
longer (up to $10 \mu \mathrm{m}$ ) capilliform filitriches were observed in the present study (Figs. 4, 5). The differences may have been caused by the measuring of filitriches from TEM and SEM photomicrographs. Marques et al. (2007) found microtriches of only $2 \mu \mathrm{m}$ in length on the scolex and body of Didymobothrium rudolphii, whereas the surface of $S$. simplex, which was studied here for the first time, is covered with capilliform filitriches up to $6 \mu \mathrm{m}$ long (Fig. 6). It can be concluded that the morphology of microtriches and their distribution are highly uniform in spathebothriidean cestodes, which appears to be a typical feature of more basal tapeworms (Levron et al. 2008, Chervy 2009).

The eggs of spathebothriideans are unique among cestodes in several aspects. They are mostly unembryonated (i.e. they do not contain a fully developed oncosphere with six hooks - a hexacanth) and operculate when laid, which resembles the situation in most caryophyllidean and some bothriocephalidean cestodes (Mackiewicz 1972, Kuchta et al. 2008). However, the eggs of spathebothriideans are unique in that the operculum is much larger (i.e. its diameter represents $20-40 \%$ of the total length of the egg) than those of other cestode groups (Bothriocephalidea, Caryophyllidea and Diphyllobothriidea), in which the diameter of the operculum always represents less than $10 \%$ of egg length, and usually only $\sim 5 \%$ (Protasova and Roitman 1995; R.K. - unpubl. data).

Another unique character of spathebothriideans that has not been observed in any group of tapeworms is the presence of external filaments on the surface of the posterior pole of the eggs of the marine genera Didymobothrium, Diplocotyle and Spathebothrium (Burt and Sandeman 1969, Munson 1974, Marques et al. 2007, present study). The function of the filaments is most likely one of adhesion to the aquatic vegetation that is foraged by amphipods (Burt and Sandeman 1969). Interestingly, these structures have never been reported on the eggs of the freshwater species B. fallax and C. truncatus (Okaka 1989, Protasova and Roitman 1995, present study), which indicates a different mode of transmission.

Molecular data allowed us to test for intraspecific variation in Diplocotyle $(\mathrm{n}=8)$ and Spathebothrium $(\mathrm{n}=2)$ for the first time, using the same variable rDNA regions that readily separate cryptic species within the genus $D i$ dymobothium (see Marques et al. 2007). However, no variation was detected, even when comparing samples collected from opposite sides of the Atlantic. This could be a reflection of low sample sizes, as species of both Spathebothrium and Diplocotyle are exceedingly difficult to obtain in the wild, or, if taken at face value, suggests that each species is panmictic across its geographical range. Interrelationships of the genera are also difficult to assess due to a high level of divergence between the taxa, but there was at least consistency among the rDNA regions (Fig. 25). Based on analyses of $28 \mathrm{~S}$ data, including an outgroup taxon (the cestodarian Amphilina foliacea),
Spathebothrium is the most basal member of the group, whereas Cyathocephalus and Didymobothrium form the most derived clade. The $18 \mathrm{~S}$ data, although only totalling $100 \mathrm{bps}$, allowed us to assess the interrelationships of all five genera with molecular data for the first time. This analysis suggests that Bothrimonus, represented by B. fallax, is most closely related to Cyathocephalus, and thus together form a freshwater clade of spathebothriideans. This affinity is also supported by their shared lack of polar filaments on the eggs (see above) (Fig. 26).

Over more than ten years, we have made numerous attempts to obtain fresh (i.e. live) specimens of B. fallax through contacts with parasitologists or ichthyologists in Eastern Europe and the Middle East. We have also enquired about the possibility of obtaining ethanol-preserved specimens from private or museum collections. However, no channel we pursued has been able to provide either fresh or ethanol-preserved specimens and it is highly likely that populations of $B$. fallax have been in decline for many years, together with most sturgeon populations, particularly in the Caspian Sea (Choudhury and Dick 2000, Bauer et al. 2002). For example, the most recent survey of sturgeon parasites in Iran found no B. fallax and reported an overall decline in parasite diversity (Sattari and Monkhayer 2005).

Consequently, this unique and interesting cestode species may well be on its way to extinction, even if its sturgeon hosts manage to survive current threats to their populations. It is therefore critical that any future collection of B. fallax minimally includes fixation of their genomic DNA (e.g. using ethanol), and ideally for examination of both gDNA and mRNA (e.g. using liquid nitrogen or RNALater (Qiagen)), as the information contained in these molecules represents the most promising historical record we have of this evolutionarily pivotal tapeworm lineage.

The relictual nature of the Spathebothriidea is indicated by their morphology, life history, biogeography and molecular data. We conclude that the five described genera, well separated by host ranges and disjunctive distributions, represent refugia of a previously more diverse and widespread clade of early-branching 'true' tapeworms, potentially the first to evolve proglottisation (i.e. repetition of the reproductive organs) as a strategy for increasing fecundity. Apart from the existence of two cryptic forms of Didymobothrium rudolphii detected by Renaud and Gabrion (1988) and Marques et al. (2007), we find no evidence to recognise multiple species in any of the genera, while providing multiple lines of data to support the distinctiveness and thus validity of the genera themselves. Having been recognised for more than 150 years, we suggest that these taxa are likely to represent the totality of extant spathebothriidean diversity, and that the sturgeonhosted species Bothrimonus fallax, if still extant, may be close to extinction as a result of significant and prolonged declines in their host populations. 
Acknowledgements. The authors are indebted to Larisa G. Poddubnaya (Russia) for providing unpublished photomicrographs of the eggs of Cyathocephalus truncatus and specimens of this species for sequencing, and to Tomáš Tyml and Andrea Bednářová (Czech Republic) for help with collecting material. This study was funded in part by the Czech Science Foundation (project No. P505/12/G112), Institute of Parasitology (project
No. RVO: 60077344), and the National Science Foundation, USA (PBI award Nos. 0818696 and 0818823). R.K.'s visits to European museums were supported by the SYNTHESYS programme of the European Communities (projects Nos. GBTAF-735 and 926, FR-TAF-3975, SE-TAF-42). Research in Svalbard was supported by the Grant No. LM2010009 CzechPolar (MŠMT ČR) and CZ.1.07/2.2.00/28.0190 (EU).

\section{REFERENCES}

Álvarez F., Iglesias R., Paramá A.I., Leiro J., Sanmartín M. 2002: Abdominal macroparasites of commercially important flatfishes (Teleostei: Scophthalmidae, Pleuronectidae, Soleidae) in northwest Spain (ICES IXa). Aquaculture 213: 31-53.

Amin O.M. 1978: On the crustacean hosts of larval acanthocephalan and cestode parasites in Southwestern Lake Michigan. J. Parasitol. 64: 842-845.

Appy R.G., Burt M.D.B. 1982: Metazoan parasites of cod, Gadus morhua L, in Canadian Atlantic waters. Can. J. Zool. 60: 1573-1579.

Bauer O.N., Pugachev O.N., Voronin V.N. 2002: Study of parasites and diseases of sturgeons in Russia: a review. J. Appl. Ichthyol. 18: 420-429.

BEVERIDGe I. 2001: The use of life-cycle characters in studies of the evolution of cestodes. In: D.T.J. Littlewood and R.A. Bray (Eds.), Interrelationships of the Platyhelminthes. The Systematics Association Special Volume Series 60. Taylor \& Francis, London and New York, pp. 250-256.

Boulllon D.R., Dempson J.B. 1989: Metazoan parasite infections in landlocked and anadromous Arctic charr (Salvelinus alpinus Linnaeus), and their use as indicators of movement to sea in young anadromous charr. Can. J. Zool. 67: 2478-2485.

Bruñanská M., Poddubnaya L.G. 2010: Spermatological characters of the spathebothriidean tapeworm Didymobothrium rudolphii (Monticelli, 1890). Parasitol. Res. 106: 1435-1442.

Burt M.D.B., Sandeman I.M. 1969: The biology of Bothrimonus (= Diplocotyle) (Pseudophyllidea: Cestoda) Part I. History, description, synonymy, and systematics. J. Fish. Res. Bd. Can. 26: 975-996.

Burt M.D.B., SAndeman I.M. 1974: The biology of Bothrimonus (=Diplocotyle) (Pseudophyllidea: Cestoda): detailed morphology and fine structure. J. Fish. Res. Bd. Can. 29: 147-153.

Caira J.N., Jensen K., Barbeau E. (Eds.) 2014: Global Cestode Database. World Wide Web electronic publication, www.tapewormdb.uconn.edu, 04/2014.

Chervy L. 2009: Unified terminology for cestode microtriches: a proposal from the International Workshops on Cestode Systematics in 2002-2008. Folia Parasitol. 56: 199-230.

Cholodkovsky N. 1914: Cestodes nouveaux un peu connus. Troisième série. Ann. Mus. Zool. Acad. Imp. Sci. St. Petrograd 19: 516-523.

Choudhury A., Dick T.A. 2000: Sturgeons (Chondrostei: Acipenseridae) and their metazoan parasites: patterns and processes in historical biogeography. J. Biogeogr. 28: 1411-1439.

Cooper A.R. 1918: North American Pseudophyllidean Cestodes from Fishes. Ill. Biol. Monogr. 4: 1-243.

Dechtiar A.O., Loftus K.H. 1965: Two new hosts for Cyathocephalus truncatus (Pallas, 1781) (Cestoda; Cyathocephalidae) in Lake Huron. Can. J. Zool. 43: 407-408.

Desdevises Y., Arthur J.R., Pellerin-Massicotte J. 1998: Parasites of anadromous arctic char (Salvelinus alpinus L.) from two sites in Ungava Bay (Quebec, Canada). J. Helminthol. Soc. Wash. 65: 87-90.

Dogiel V.A., Bychowsky B.E. 1938: [Parasites of the Caspian fish.] Tr. Kompleks. Izuch. Kaspiiskogo Morya 7: 1-179. (In Russian.)

Duvernoy M. 1842: Note sur un nouveau genre de ver intestinal, de la famille des Ténioïdes, le Bothrimone de l'esturgeon (Bothrimonus sturionis, Nob.). Ann. Sci. Nat. Zool. 18: 123-126.

Gibson D.I. 1994: Order Spathebothriidea Wardle and McLeod, 1952. In: L.F. Khalil, A. Jones and R.A. Bray (Eds.), Keys to the Cestode Parasites of Vertebrates. CAB International, Wallingford, pp. 15-19.

HALDORSON L. 1984: A seasonal survey of metazoan parasites of Arctic cisco (Coregonus autumnalis) from Alaskan arctic coastal waters. Proc. Helminthol. Soc. Wash. 51: 245-247.

Hansson H.G. 1998: NEAT (North East Atlantic Taxa): South Scandinavian marine Plathelminthes Check-List. World Wide Wed, www.tmbl.gu.se/libdb/taxon/neat_pdf/ NEAT*Plathelmint.pdf, 08/1998.

Hart J.F., Guberlet J.E. 1936: Cestoda from fishes of Puget Sound. I. Spathebothrioidea, a new superfamily. Trans. Am. Microsc. Soc. 2: 199-207.

Huitfeldt-KaAs H. 1927: Cyathocephalus truncatus Pall. als Ursache von Fisch-Epizootien. Nytt. Mag. Naturvid. 65: 143151.

IVANOV V.P. 1968: [Parasite fauna of sturgeons naturally and artificially reared in a fish farm in the Volga River.] PhD thesis, Volgograd, 20 pp. (Cited from Izyumova 1977; in Russian.).

Izyumova N.A. 1977: [Fish Parasite Fauna of Water Reservoirs of the USSR and its Formation.] Nauka, Moscow, 283 pp. (In Russian.)

Khalil L.F., Jones A., Bray R.A. 1994: Keys to the Cestode Parasites of Vertebrates. CAB International, Wallingford, 768 pp.

Knudsen R., Gabler H.M., Kuris A.M., Amundsen P-.A. 2001: Selective predation on parasitized prey - a comparison between two helminth species with different life-history strategies. J. Parasitol. 87: 941-945.

Kodedová I., Doležel D., Broučková M., Jirků M., HypšA V., Lukeš J., SCHOLZ T. 2000: On the phylogenetic positions of the Caryophyllidea, Pseudophyllidea and Proteocephalidea (Eucestoda) inferred from 18S rRNA. Int. J. Parasitol. 30: 1109-1113.

Krabbe H. 1874: Diplocotyle olrikii, Cestoide non articulé du group des Bothriocéphales. Videnskabelige Meddelelser fra Dansk naturhistorisk Forening i Kjobenhavn 1874: 22-25.

Kuchta R., Caira J.N. 2010: Three new species of Echinobothrium (Cestoda: Diphyllidea) from Indo-Pacific stingrays of the genus Pastinachus. Folia Parasitol. 57: 185-196.

Kuchta R., Scholz T., BRAY R.A. 2008: Revision of the order Bothriocephalidea Kuchta, Scholz, Brabec \& Bray, 2008 
(Eucestoda) with amended generic diagnoses and keys to families and genera. Syst. Parasitol. 71: 81-136.

Levron C., Scholz T., Dezfuli S. 2008: Ultrastructure of microtriches on the scolex of Cyathocephalus truncatus (Cestoda: Spathebothriidea). Folia Parasitol. 55: 309-312.

LinKLetTer L.E. 1977: A Checklist of Marine Fauna and Flora of the Bay of Fundy. Huntsman Marine Laboratory, St. Andrews, New Brunsvick, 68 pp.

Linton E. 1922: A new cestode from Liparis liparis. Trans. Am. Microsc. Soc. 41: 118-121.

Linton E. 1941: Cestode parasites of teleost fishes of the Woods Hole region, Massachusetts. Proc. U. S. Nat. Mus. 12: 417-442.

Littlewood D.T.J., Waeschenbach A., Nikolov P.N. 2008: In search of mitochondrial markers for resolving the phylogeny of cyclophyllidean tapeworms (Platyhelminthes, Cestoda) - a test study with Davaineidae. Acta Parasitol. 53: 133-144.

LÜHE M. 1900: Über Bothrimonus Duv. und verwandte Bothriocephaliden. Zool. Anz. 23: 8-14.

Machida M., Araki J. 1992: Some trematodes and cestodes from the Okhotsk Sea off Hokkaido, Japan. Mem. Nat. Sci. Mus. Tokyo 25: 97-103.

Machida M., Araki J. 1994: Some trematodes and cestodes in fishes from off eastern Hokkaido, northern Japan. Mem. Nat. Sci. Mus. Tokyo 27: 87-92.

Mackiewicz J.S. 1972: Caryophyllidea (Cestoidea): a review. Exp. Parasitol. 34: 417-512.

Mamedova S.N. 2005: Fauna and ecology of the Caspian Sea sturgeons (Acipenseridae) parasites near coasts of Absheron Peninsula. Baku Univ. News 1: 88-94.

Markevich A.P. 1951: [Parasite Fauna of Freshwater Fishes of Ukraine.] Publ. House of the Ukrainian Academy of Sciences, Kiev, 388 pp. (In Russian.)

Markov G.S., Trusov V.Z., Ivanov V.P. 1967: [Distribution of some parasites of acipenserid fishes in northern Caspian Sea.] Sb. Nauchn. Rabot Volgogradskogo Pedagog. Inst. 2: 180-182. (In Russian.)

Marques J., Cabral H.N. 2007: Effects of sample size on fish parasite prevalence, mean abundance and mean intensity estimates. J. Appl. Ichthyol. 23: 158-162.

Marques J., Santos M.J., Gibson D.I., Cabral H.N., OlSON P.D. 2007: Cryptic species of Didymobothrium rudolphii (Cestoda: Spathebothriidea) from the sand sole, Solea lascaris, off the Portuguese coast, with an analysis of their molecules, morphology, ultrastructure and phylogeny. Parasitology 134 : 1057-1072.

McDonald T.E., Margolis L. 1995: Synopsis of the parasites of fishes of Canada: Supplement (1978-1993). Can. Spec. Publ. Fish. Aquat. Sci. 122: 1-265

Mikailov T.K. 1963: [Parasites of commercial fishes of the Kura River.] Materials of the scientific conference of helminthologists of Transcaucasian republics, 28-30 October 1961. Publ. House of the Georgian Academy of Sciences, Tbilisi. (Cited after Skryabina 1974; in Russian.)

Moszczynska A., Locke S.A., McLaughlin D., MarCOglieses D.J., Crease T.J. 2009: Development of primers for the mitochondrial cytochrome $c$ oxidase gene in digenetic trematodes (Platyhelminthes) illustrates the challenge of barcoding parasitic helminths. Mol. Ecol. Resour. 9: 75-82.

Munson D.A. 1974: Parasites of the tide pool fish Liparis atlanticus (Osteichthyes: Liparidae). J. Wildl. Dis. 10: 256-262.

Muzzall P.M. 1980: Host-parasite relationships of Spathebothrium simplex Linton, 1922 (Cestoda: Spathebothriidae) infecting the seasnail, Liparis atlanticus (Jordan and Everman, 1898)
(Osteichthyes: Liparidae). Proc. Helminthol. Soc. Wash. 47: 30-32.

NahHas F.M., Krupin R. 1977: Parasites of Liparis callyodon (Pallas) with a description of a new species, Metadena caballeroi. Excerta Parasitológica en Memoria del Doctor Eduardo Caballero y Caballero. Instituto de Biología, Universidad Nacional Autónoma de Mexico, Mexico City, Publicaciones Especiales 4: 261-266.

NoEI M.R. 2010: On helminth fauna of sturgeons (Acipenseridae) in nearshore area of Iranian sector of the Caspian Sea. Proc. Conf. "Theoretical and Practical Problems of Parasitology", 30 November-3 December 2010, Moscow, pp. 455-458.

Noer M.R. 2011: Parasitic worms of Acipenser stellatus, A. gueldenstaedtii, A. nudiventris and Huso huso (Chondrostei: Acipenseridae) from the southwest shores of the Caspian Sea. Caspian J. Environ. Sci. 9: 257-266.

Nybelin O. 1922: Anatomisch-systematische Studien über Pseudophyllideen. Göteborgs kungl. Vetenskaps-och VitterhetsSamhälles Handlingar XXVI, Med bihang 41: 1-128.

Nylander J.A.A. 2008: MrModelTest v2.3. Program distributed by the author. Evolutionary Biology Centre, Uppsala University.

Oguz M.C., Bray R.A. 2008. Cestoda and Monogenea of some teleost fishes off the Mudanya Coast (Sea of Marmara, Turkey). Helminthologia 45: 192-195.

Окака C.E. 1989: Studies on the development of the oncosphere and procercoid of Cyathocephalus truncatus (Cestoda) in the intermediate host, Gammarus pulex. Zool. Scr. 18: 205-209.

Oкака C.E. 2000: Maturity of the procercoid of Cyathocephalus truncatus (Eucestoda: Spathebothriidae) in Gammarus pulex (Crustacea: Amphipoda) and the tapeworms life cycle using the amphipod as the sole host. Helminthologia 37: 153-157.

Olson P.D., Caira J.N. 1999: Evolution of the major lineages of tapeworms (Platyhelminthes: Cestoidea) inferred from $18 \mathrm{~S}$ ribosomal DNA and elongation factor-1 $\alpha$. J. Parasitol. 85: 1134-1159.

Olson P.D., Littlewood D.T.J., Bray R.A., Mariaux J. 2001: Interrelationships and evolution of the tapeworms (Platyhelminthes: Cestoda). Mol. Phylogenet. Evol. 18: 443-467.

Olson P.D., Poddubnaya L.G., Littlewood D.T.J., Scholz T. 2008: On the position of Archigetes and its bearing on the early evolution of the tapeworms. J. Parasitol. 94: 898-904.

Orecchia P., Paggi L., Minervini R., Di Cave D. 1985: La parassitofauna delle specie ittiche strascicabili presenti alla foce del fiume Tevere. Oebalia 11: 623-632.

Pallas P.S. 1781: Bemerkungen über die Bandwürmer in Menschen und Thieren. Neue nordische Beyträge zur physikalischen und geographischen Erd- und Völkerbeschreibung, Naturgeschichte und Oekonomie. 1. Band, St. Petersburg und Leipzig, pp. 39-112.

PAPoutsoglou S.E. 1976: Metazoan parasites of fishes from Saronicos Gulf Athens - Greece. Thalassographica 1: 69-102.

Poddubnaya L.G., Gibson D.I., Olson P.D. 2007: Ultrastructure of the ovary, ovicapt and oviduct of the spathebothriidean tapeworm Didymobothrium rudolphii (Monticelli, 1890). Acta Parasitol. 52: 127-134.

Poddubnaya L.G., Gibson D.I., Swiderski Z., Olson P.D. 2006: Vitellocyte ultrastructure in the cestode Didymobothrium rudolphii (Monticelli, 1890): possible evidence for the recognition of divergent taxa within the Spathebothriidea. Acta Parasitol. 51: 255-263. 
POLYANSKII YU. I. 1955: [Materials to fish parasitology of northern seas of the USSR.] Trudy Zool. Inst. AN SSSR 19: 5-170. (In Russian.)

Protasova E.N., Reggel K.V., Atrashkevich G.I. 2010: [Occurrence of Spathebothrium simplex and Diplocotyle olriki (Cestoda, Pseudophyllidea, Cyathocephalata) procercoids in amphipods from the northern part of the Sea of Okhotsk.] Zool. Zh. 89: 939-947. (In Russian.)

Protasova E.N., Roitman V.A. 1995: [Cyathocephalates, Tapeworm Helminths of Marine and Freshwater Fishes (Cestoda: Pseudophyllidea: Cyathocephalata).] Essentials of Cestodology. Vol. 12. Nauka, Moscow, 134 pp. (In Russian.)

Renaud F., Gabrion C. 1988: Speciation in Cestoda: evidence for two sibling species in the complex Bothrimonus nylandicus (Schneider 1902) (Cestoda: Cyathocephalidea). Parasitology 97: 139-147.

Sandeman I.M., Burt M.D.B. 1972: The biology of Bothrimonus (= Diplocotyle) (Pseudophyllidea: Cestoda): ecology, life cycle, and evolution; a review and synthesis. J. Fish. Res. Bd. Can. 29: 1381-1395.

Sanmartín Durán M.L., Quinteiro Alonso P., Rodriguez A., Fernández A. 1989: Some Spanish cestode fish parasites. J. Fish Biol. 34: 977-978.

Sattari M. 2002: Parasitic worms of stellate sturgeon (Acipenser stellatus) from the southwest of the Caspian Sea. Casp. J. Env. Sci. 1: 53-60.

Sattari M., Mokhayer B. 2005. Occurrence and intensity of some parasitic worms in Acipenser gueldenstaedti, A. nudiventris and Huso huso (Chondrostei: Acipenseridae) from the southwest of the Caspian Sea. Turk. J. Vet. Anim. Sci. 29: 1279-1284.

SChмidT G.D. 1986: CRC Handbook of Tapeworm Identification. CRC Press, Boca Raton, Florida, 675 pp.

Skryabina E.S. 1974: [Helminths of Acipenserid Fishes.] Nauka, Moscow, 168 pp. (In Russian.)
Sudarikov V.E., Kurochkin V.E. 1964: [Finding of larvae of cestodes of sturgeons - Bothrimonus fallax Lühe, 1900 in amphipods of the Caspian Sea.] Tr. Astrakhan. Gos. Zapovednika 9: 214-218. (In Russian.)

Swiderski Z., Gibson D.I., Santos M.J., Poddubnaya L.G. 2010: Ultrastructure of the intrauterine eggs of Didymobothrium rudolphii (Monticelli, 1890) (Cestoda, Spathebothriidea, Acrobothriidae) and its phylogenetic implications. Acta Parasitol. 55: 254-269.

VIK R. 1958: Studies of helminth fauna of Norway II. Distribution and life cycle of Cyathocephalus truncatus (Pallas, 1781) (Cestoda). Nytt Mag. Zool. 6: 97-110.

Volz W. 1899: Faune de la Roumanie. Helminthes trouvés par Mr. Jaquet et determinés par M. Walter Volz. Bull. Soc. Sci., Bucharest 8: 312-314.

Waeschenbach A., Webster B., Bray R.A., Littlewood D.T.J. 2007: Added resolution among ordinal level relationships of tapeworms (Platyhelminthes: Cestoda) with complete small and large subunit nuclear ribosomal RNA genes. Mol. Phylogenet. Evol. 45: 311-325.

Waeschenbach A., Webster B., Bray, R.A., Littlewood D.T.J. 2012: Adding resolution to ordinal level relationships of tapeworms (Platyhelminthes: Cestoda) with large fragments of mtDNA. Mol. Phylogenet. Evol. 63: 834-847.

Wardle R.A., McLeod J.A. 1952: The Zoology of Tapeworms. University of Minnesota Press, Minneapolis, $780 \mathrm{pp}$.

WiŚnieWski L.W. 1932: I. Die Postembryonalentwicklung und Biologie. Bull. Acad. Pol. Sci. Cl. Sci. Math. Nat. B 3: 237-252.

Yamaguti S. 1934: Studies on the helminth fauna of Japan. Part 4. Cestodes of fishes. Jpn. J. Zool. 6: 1-112.

Zhuкov E.V. 1963: [On the fauna of parasites of fish of the Chukotsk Peninsula and adjoining seas. II. Endoparasitic worms of marine and freshwater fishes.] Parazitol. Sborn. Zool. Inst. Akad. Nauk SSSR 21: 96-139. (In Russian.) 